Journal of Science Education Research

Journal homepage: www.journal.uny.ac.id/jser

JSER

\title{
ANALYSES OF JUNIOR HIGH SCHOOL SCIENCE COMPETENCIES IN KTSP AND INTEGRATED-REVISION OF 2013 CURRICULUM: REVIEWED FROM THE POTENTIAL OF DISASTER MITIGATION EDUCATION FOR THE SHAPING OF A DISASTER RESPONSE CHARACTER
}

\author{
Rangga Sena Aji Hamisesa, Fitri Handayani Nataliya, Reno Nurdiyanto, Pujianto \\ Physics Education, Yogyakarta State University \\ Corresponding Author. Email: rangga.sena2016@student.uny.ac.id
}

Keywords:
KTSP, revised of
K-13, character,
natural disaster
mitigation,
science

Keywords:

KTSP, revised of natural disaster science

\begin{abstract}
This study aims to analyze the science competencies in the JHS (Junior High Schools) which is integrated to disaster mitigation education (earthquake, tsunami, and volcano) in the School-Based Curriculum (KTSP) and the revised 2013 Curriculum in shaping a disaster response character. This study focuses on operational competencies that are potential to be integrated with disaster mitigation education, especially geological disasters. This was a library research analyzing any issues (problems) based on supporting literature reviewed. The data were collected through documentation, observation, and recorded findings that support to the research focus. As many as 40 science teachers and all documents of the implementation of the KTSP and revised-2013 Curriculum were involved in this study. Then the data were analyzed using a coding technique according to the components of the research focus and described qualitatively. The results of the study show that the number of science-competencies which have the potential to be integrated with disaster mitigation education is considered low compared to the whole of Science competencies that students must achieve. $0.48 \%$ of sciencecompetencies in JHS are potential to be integrated with disaster mitigation education. These competencies are $0.72 \%$ in grade VII, $0.25 \%$ in grade VIII, and $0.5 \%$ in grade IX. These findings indicate that the contents of the curriculum have not been considered as a means of instilling the natural disaster response character.
\end{abstract}

C2018 JSER. Yogyakarta State University

\section{INTRODUCTION}

Based on the Regulation of the Minister of Education and Culture (Permendikbud) Number 61 of 2014 on the School-Based Curriculum (KTSP) in Primary and Secondary Schools in article (1), it is stated that the KTSP is an operational curriculum compiled by and implemented in each education unit. In implementing the curriculum, schools can administer teaching-learning activities in accordance with the needs and set the Minimum Completeness Criteria (KKM) mutually agreed. It is also stated in article 2, paragraph 1 that the KTSP is developed, established, and implemented by each education unit. In developing school needs, there is a conceptual reference as written in article 3 paragraph 2 . One of the indicators is that the conceptual reference at least covers the diversity of potential and characteristics of the region and environment. Thus, according to this reference, the potential and characteristics of the region and the school environment cannot be separated from the surrounding natural phenomena that can be contained in the science subjects. Natural phenomena that can be included in the science subjects are one of the potential disasters in an area in disaster mitigation measures.

Since the KTSP is considered lacking in generating scientific explanations related to disaster potential and disaster mitigation measures, 
a new curriculum is needed, namely the 2013 Curriculum. This curriculum is developed from the 2006 curriculum (KTSP), one of which is based on future challenges, public perceptions and negative phenomena arising. According to the reference, the challenges of the future in the implementation of education in Indonesia can be defined as the risk of natural disasters, the perception of the people who still ignore the importance of disaster mitigation education, and the negative phenomena referring to natural disasters. The K-13 contents expect students to be equipped with the ability to identify, map, and analyze the potential of natural disasters in Indonesia and to apply disaster mitigation education. These will make natural disasters as objects that can be studied and explained scientifically, so students can disseminate the information to the closest family and the public so that the victims can be minimized. Lack of knowledge about the steps to anticipate a natural disaster among the society is one factor causing the occurrence of the victims of the natural disasters. Therefore, it is necessary to investigate and further examine whether the contents of disaster mitigation have been included in the Basic Competencies (KD) and the Core Competencies (KI) in the curriculum so that the impacts of the disaster can be reduced, and the victims of the natural disasters can be minimized.

\section{METHOD}

1) The design of this study was library research conducted in several steps, namely

a. searching for literature both in the form of journals and those that can be the basis of these research theories,

b. looking for sources from the Minister of Education and Culture and the attachments,

c. looking for the Competency Standards (SK) and the Basic Competencies (KD) in the KTSP and the Basic Competencies (KD) and the Core Competencies (KI) in the 2013 Curriculum (K-13) to examine whether the materials are integrated with disaster mitigation education,

d. giving a special code on the selected materials examined, and e. giving the percentage on each material encoded with the sum of all the KD and KI for the K-13 and the SK and KD for all KTSP science materials.

2) The population of this study included all the $\mathrm{KD}$ and $\mathrm{KI}$ in the K-13 and the SK-KD in the KTSP of grades VII, VIII, and IX of Junior High Schools materials. The samples were taken from the materials contained in the KD and $\mathrm{KI}$ as well as the specifically encoded SK and $\mathrm{KD}$.

3) The data collection techniques were by looking for literature on the Minister of Education and Culture and the attachments and books integrated with natural disaster education whose science materials were reviewed whether they could be inserted into disaster education material. For the development of instruments, the data would be more valid by distributing short questionnaires to find out what curriculum the science teacher candidates had been applied in schools they worked. Then the percentage of the use of the curriculum by several science teacher candidates in the samples of schools was also analyzed

\section{RESULT}

The competency Standards (SK) and Basic Competencies (KD) of science in the Junior High Schools (JHS) are the minimum standards that must be nationally achieved by students and become a reference in curriculum development in each education unit. The achievement of the SK and $\mathrm{KD}$ is based on the empowerment of the students to build capacity, work scientifically, and gain knowledge facilitated by the teachers. The science materials of the Junior High Schools is the continuation of the science materials students have learned in the JHS covering the following aspects:

(1) Living things and the Life Process,

(2) Materials and Their Properties,

(3) Energy and Change, and

(4) The Earth and the Universe.

The Basic Competencies and Competency Standards can be formulated as follows.

\begin{tabular}{cc}
\hline & Grade VII \\
\hline COMPETENCY & BASIC COMPETENCIES \\
STANDARDS & \\
\hline & Semester I \\
\hline
\end{tabular}

\begin{tabular}{ll} 
1. Understanding & 1.1 Describing base units and derived units \\
scientific procedures & 1.2. Describing temperature and the measurements \\
to learn natural & 1.3 Performing basic measurements carefully using measuring \\
\hline
\end{tabular}




\begin{tabular}{cc}
\hline & Grade VII \\
\hline COMPETENCY & BASIC COMPETENCIES \\
STANDARDS & \\
\hline
\end{tabular}

objects using

equipment

2. Understanding the classification of substances
2.1 Grouping the properties of acidic solutions, alkaline solutions and salt solutions with the right tools and indicators of achievement of competency

2.2 Conducting simple experiments with materials obtained in daily life

2.3 Explaining names of elements and simple chemical formulas

2.4 Comparing the properties of elements, compounds, and mixtures

3.1 Investigating the properties of matters based on their forms and the applications in daily life

3.2 Conducting experiments related to expansion in daily life

3.3 Describing the role of heat in changing the nature of matters and the temperature of objects and the applications in daily life
4. Understanding various properties in physical and chemical changes
4.1 Comparing the physical and chemical properties of matters

4.2 Performing mixture separation with various methods based on physical and chemical properties

4.3 Concluding physical and chemical changes based on the results of simple experiments

4.4 Identifing the occurrence of chemical reactions through simple experiments

\section{Semester II}

5. Understanding natural phenomena through observation
5.1 Carrying out observations of objects in a planned and systematic way to obtain information on the biotic and abiotic natural phenomena

5.2 Analyzing the data of experiments on the uniform rectilinear motion and the uniformly accelerated rectilinear motion as well as the applications in daily life

5.3 Using a microscope and other supporting equipment to observe the phenomena of life

5.4 Applying work safety in observing natural phenomena
6.1 Identifing the characteristics of living things

6.2 Classifying living things based on their characteristics

6.3 Describing diversity in organizational systems of life from the cellular level to the organism level
7. Understanding interdependence in ecosystems
7.1 Determining ecosystems and the interdependence between the components of ecosystems

7.2 Identifying the importance of diversity of living things in 


\begin{tabular}{|c|c|}
\hline \multicolumn{2}{|r|}{ Grade VII } \\
\hline $\begin{array}{c}\text { COMPETENCY } \\
\text { STANDARDS }\end{array}$ & BASIC COMPETENCIES \\
\hline \multicolumn{2}{|r|}{ Semester I } \\
\hline & $\begin{array}{l}\text { ecosystem preservation } \\
\text { 7.3 Predicting the effect of human population density on the } \\
\text { environment } \\
\text { 7.4 Applying the role of humans in environmental management to } \\
\text { overcome pollution and environmental damage }\end{array}$ \\
\hline \multicolumn{2}{|r|}{ Grade VIII } \\
\hline $\begin{array}{l}\text { COMPETENCY } \\
\text { STANDARDS }\end{array}$ & BASIC COMPETENCIES \\
\hline \multicolumn{2}{|r|}{ Semester I } \\
\hline $\begin{array}{l}\text { 1. Understanding } \\
\text { various systems in } \\
\text { human life }\end{array}$ & $\begin{array}{l}\text { 1.1 Analyzing the importance of growth and development in living } \\
\text { things } \\
\text { 1.2 Describing the stages of human development } \\
\text { 1.3 Describing the movement system of humans and the correlations } \\
\text { to health } \\
\text { 1.4 Describing the digestive system of humans and the correlations } \\
\text { to health } \\
\text { 1.5 Describing the respiratory system of humans and the correlations } \\
\text { to health. } \\
\text { 1.6 Describing the circulatory system of humans and the correlations } \\
\text { to health. }\end{array}$ \\
\hline
\end{tabular}

2. Understanding systems in plant life

\subsection{Identifying the structures and functions of plant tissue}

2.2 Describing the processes of obtaining nutrition and transforming energy in green plants

2.3 Identifying the types of movement in plants

2.4 Identifying pests and diseases in plant organs found in daily life
3.1 Explaining the concepts of atoms, ions. and molecules

3.2 Linking the concepts of atoms, ions, and molecules with daily chemical products

3.3 Comparing elemental molecules and compound molecules
4. Understanding the uses of chemicals in life

\subsection{Finding information about the uses and side effects of chemicals} in daily life

4.2 Communicating the information about the uses and side effects of chemicals

4..3 Describing natural chemicals and artificial chemicals in food packaging

4.4 Describing the properties/influences of addictive and psychotropic substances

4.5 Avoiding addictive and psychotropic substances

\section{Semester II}

5. Understanding the role of work, force,
5.1 Identifying the types of force, the equation of force, and their effects on objects subject to force 


\begin{tabular}{|c|c|}
\hline \multicolumn{2}{|r|}{ Grade VIII } \\
\hline COMPETENCY & BASIC COMPETENCIES \\
\hline \multicolumn{2}{|r|}{ Semester I } \\
\hline and energy in daily & 5.2 Applying Newton's law to explain various events in daily life \\
\hline life & $\begin{array}{l}\text { 5.3 Explaining the correlations between the forms of energy and the } \\
\text { changes, the principle of "work and energy", and the applications in } \\
\text { daily life } \\
\text { 5.4 Conducting experiments on simple machines and their } \\
\text { applications in everyday life } \\
5.5 \text { Investigating pressure on solid, liquid, and gas objects and the } \\
\text { applications in daily life }\end{array}$ \\
\hline
\end{tabular}

6. Understanding the concepts and applications of vibrations, waves, and optics in the products of technology in daily life
6.1 Describing the concepts of vibration, waves, and their parameters 6.2 Describing the concepts of in daily life

6.3 Investigating the properties of light and their correlations to the various forms of mirrors and lenses

6.4 Describing optical devices and their applications in daily life

\begin{tabular}{lc}
\hline & Grade IX \\
\hline COMPETENCY & BASIC COMPETENCIES \\
STANDARDS & \\
\hline
\end{tabular}

\section{Semester I}

1. Understanding various systems in human life
1.1 Describing the excretory system of humans and its correlation to health

1.2 Describing the reproductive system and diseases related to the reproductive system of humans

1.3 Describing the coordination system and sense organs of humans and their correlation to health
2. Understanding the survival of living things
2.1 Identifying the survival of living things through adaptation, natural selection, and mating

2.2 Describing the concept of heredity in living things

2.3 Describing the heredity process, the results of the heredity process, and its applications

2.4 Describing the applications of biotechnology in supporting the survival of humans through food production
3. Understanding the concept of electricity and its applications in daily life
3.1 Describing electric charges to understand the phenomena of static electricity and their correlations in daily life

3.2 Analyzing dynamic electrical experiments in electrical circuits their applications in daily life

3.3 Describing the principles of the elements and the electric currents they cause and their applications in daily life

3.4 Describing the correlations between energy and electric power and the uses in daily life 
Semester II

4. Understanding the concept of magnetism and its applications in daily life
4.1 Investigating the phenomena of magnetism and how to make magnets

4.2 Describing the utilization of magnets in technological products

4.3 Applying the concept of electromagnetic induction to explain the principles of several devices that utilize the principles of electromagnetic induction
5. Understanding the solar system and the processes that occur in it
5.1 Describing the characteristics of the solar system

5.2 Describing the sun as a star and earth as one of the planets

5.3 Describing the motion of the earth, moon, and artificial satellites and the effect of their interactions

5.4 Describing the specific processes that occur in the lithosphere and atmosphere related to changes in substances and heat

5.5 Explaining the correlations between processes that occur in the lithosphere and atmosphere with health and environmental problems
Based on the $\mathrm{KD}$ and $\mathrm{KI}$ in the $\mathrm{K}-13$ of science of the JHS Grade VII, VIII, and IX, the curriculum objectives include four competencies, namely (1) spiritual attitude competency, (2) social attitudes, (3) knowledge, and (4) skills. Those competencies are achieved through the intracurricular, cocurricular, and/or extracurricular teaching-learning processes. The formulation of the spiritual attitude competency is "respecting and appreciating the teachings of the religion adhered to". As for the formulation of the social attitude competency is "showing honest behavior, discipline, responsibility, caring (tolerance, mutual cooperation), courtesy, and self-confidence in the social environment and existence". Both of these competencies are achieved through indirect teaching, namely exemplary behavior, accustoming, and school culture by considering the characteristics of the subjects and the needs and conditions of the students. The competencies can be grown and developed throughout the teachinglearning processes and can be used as a teachers' consideration to further develop the characters of the students. The competencies of knowledge and skills can be formulated as follows.

\section{Grade VII}

CORE COMPETENCY 3

CORE COMPETENCY 4 (KETERAMPILAN) (KNOWLEDGE)

3. Understanding knowledge

(factual, conceptual, and procedural) based on the curiosity about science, technology, art, and culture related to visible phenomena and events
4. Trying, processing, and presenting in concrete realms (using, explaining, compiling, modifying, and making) and abstract domains (writing, reading, counting, drawing, and composing) according to what is learned in schools and other similar sources in the point of view/theory

\section{BASIC COMPETENCIES}

\section{BASIC COMPETENCIES}

3.1 Applying the concept of measuring various quantities using standard units
4.1 Presenting measurement data with appropriate measuring instruments to themselves, other living things, and objects around using nonstandard and standard units 
objects based on observed characteristics and objects in the surrounding environment based on observed characteristics
3.3 Explaining the concepts of mixtures and single substances (elements and compounds), physical and chemical properties, and physical and chemical changes in everyday life
4.3 Presenting the results of investigations or works about the nature of solutions, physical and chemical changes, or separation of mixtures

\subsection{Analyzing the concepts of} temperature, expansion, heat, heat transfer, and the applications in daily life including mechanisms to maintain body temperature stability in humans and animals

3.5 Analyzing the concepts of energy, various energy sources and changes in the forms of energy in daily life including photosynthesis

\subsection{Identifying organizational} systems of life from the cellular level to the organism level and the main composition of cells

\subsection{Analyzing the interactions} between living things and their environment as well as the dynamics of population resulting from these interactions

\subsection{Analyzing the occurrence of} environmental pollution and its impact on the ecosystem

3.9 Analyzing climate change and its impacts on the ecosystem.

3.10 Describing the earth's layers, volcanoes, earthquakes, and risk management before, at, during and post-disaster according to the disaster risks in the area
4.4 Conducting experiments to investigate the effects of heat on the temperature and shape of objects and heat transfer

4.5 Presenting the results of experiments about changes in the forms of energy, including photosynthesis

\subsection{Modeling plant/animal cell structures}

4.7 Presenting observations on the interactions of living things with the surrounding environment

4.8 Writing about the idea of resolving pollution problems in the environment based on observations

4.9 Writing about the idea of adaptation/coping with climate change problems

4.10 Communicating efforts to reduce risks and impacts of natural disasters as well as actions to save themselves in a disaster based on the types of disaster in their area 
3.11 Analyzing the solar system, rotation, and revolution of the earth, the rotation and revolution of the moon, and the effects on life on earth
4.11 Presenting works on the effects of rotation and revolution of the earth and moon for life on earth, based on the results of observations or tracing various sources of information

\begin{tabular}{lc}
\hline & Grade VIII \\
\hline $\begin{array}{l}\text { CORE COMPETENCIES } 3 \\
\text { (KNOWLEDGE) }\end{array}$ & CORE COMPETENCIES 4 (SKILLS) \\
\hline
\end{tabular}

3. Understanding and applying knowledge (factual, conceptual, and procedural) based on the curiosity about science, technology, art, and culture related to visible phenomena and events

\section{BASIC COMPETENCIES}

\subsection{Analyzing motions in living} things, movement systems of humans, and efforts to maintain the health of the movement system

3.2 Analyzing rectilinear motions, the influence of force on motions based on the Newton's Law, and the applications to the motions of objects and living things

\subsection{Explaining the concepts of} work, simple machines, and the application in daily life including the work of muscles in human skeletal structures

\subsection{Analyzing the} interrelationships of plant tissue structures and their functions, as well as technologies inspired by plant structures

3.5 Analyzing the digestive system of humans and understanding disorders related to the digestive system, as well as efforts to maintain the health of the digestive system
4. Processing, presenting, and reasoning in concrete realms (using, explaining, compiling, modifying, and making) and abstract domains (writing, reading, counting, drawing, and composing) according to what is learned in schools and other similar sources in the point of view/theory

\section{BASIC COMPETENCIES}

4.1 Presenting works on various disorders of the movement system, as well as efforts to maintain the health of the movement system

4.2 Presenting the results of investigations about the influence of force on the motions of objects

4.3 Presenting the results of investigations or problem solving about the benefits and uses of simple machines in daily life

4.4 Presenting works from the results after searching for various sources of information about technology inspired by observations of plant structures

4.5 Presenting results of investigations on mechanical and chemical digestion 
3.6 Describing various additives in food and beverages, addictive substances, and their impact on health
4.6 Composing written works on the effects of abusing additives and the impacts of addictive substances on health
3.7 Analyzing the circulatory system of humans and understanding disorders of the circulatory system, as well as efforts to maintain the health of the circulatory system

\subsection{Explaining pressure on} substances and the applications in daily life, including blood pressure and the osmosis and capillary of the vascular tissue in plants

3.9 Analyze the respiratory system of humans and understanding disorders of the respiratory system, as well as efforts to maintain the health of the respiratory system

\subsection{Analyzing the excretory} system in humans and understanding disorders of the excretory system and efforts to maintain the health of the excretory system

3.11 Analyzing the concepts of vibration, waves, and sounds in daily life including the human hearing system and sonar systems in animals

\subsection{Analyzing the properties of} light, the formation of reflections in flat and curved surfaces and their applications to explain the human visual system, insect eyes and the principles of optical devices
4.7 Presenting the results of experiments on the effects of activities (type, intensity, or duration) on the heart rate

4.8 Presenting the data of experiments to investigate the pressure on liquids at certain pressures, buoyancy and capillary forces, such as in plant stems

4.9 Presenting works on efforts to maintain the health of the respiratory system

4.10 Making works about the excretory system of humans and the applications in maintaining personal health

4.11 Presenting the results of experiments about vibrations, waves, and sounds

4.12 Presenting the results of experiments about the formation of reflections on mirrors and lenses 
Grade IX

\section{CORE COMPETENCIES 3}

CORE COMPETENCIES 4 (SKILLS)

(KNOWLEDGE)

3. Understanding knowledge

(factual, conceptual, and procedural) based on the curiosity about science, technology, art, and culture related to visible phenomena and events

\section{BASIC COMPETENCIES}

3.1 Connecting the reproductive system of humans and disorders of the reproductive system with the application of living patterns that support reproductive health

\subsection{Analyzing the reproductive} system plants and animals and applying technology to the reproductive system of plants and animals

\subsection{Applying the concept of} heredity in breeding and survival of living things

\subsection{Explaining the concepts of} static electricity and the phenomena in daily life, including electricity in the nervous system and animals that contain electricity

3.5 Applying the concepts of electrical circuits, energy, and electric power, electrical energy sources in daily life including alternative electrical energy sources, and various efforts to save electricity

\subsection{Applying the concepts of} magnetism, electromagnetic induction, and the use of magnetic fields in daily life including movement/navigation of animals to find food and migrate
4. Processing, presenting, and reasoning in concrete realms (using, explaining, compiling, modifying, and making) and abstract domains (writing, reading, counting, drawing, and composing) according to what is learned in schools and other similar sources in the point of view/theory

\section{BASIC COMPETENCIES}

4.1 Presenting the results after searching for information from various sources related to health and efforts to prevent disorders of the reproductive organs

\subsection{Presenting works on plant breeding}

4.3 Presenting the results after searching for information from various sources on breeding of plants and animals

4.4 Presenting the results of observations about the phenomena of static electricity in daily life

\subsection{Presenting the results of the design and} measurement of various electrical circuits

4.6 Making simple works that utilize electromagnetic principles and/or electromagnetic induction 
biotechnology and its roles in human life

\subsection{Linking the concepts of} material particles (atoms, ions, and molecules), the structures of simple substances with the properties of materials used in daily life, and the impact of their use on human health

\subsection{Connecting the physical and} chemical properties of soil, organisms that live in soil, with the importance of soil to sustainable life

\subsection{Analyzing environmentally} friendly processes and products of technology for sustainable life the surrounding environment

4.8 Presenting the results of investigations about the nature and use of materials in daily life
4.9 Presenting the results of investigations on the properties of soil and the importance of soil to life
4.10 Presenting works on simple technological processes and products of technology that are environmentally friendly
The library research conducted has found out that the percentage of science materials in the KD of the KTSP which can be integrated with the disaster mitigation education. As many as $0.14 \%$ of the Junior High School science Basic Competencies using the KTSP has the potential to be used as an integration of the natural disaster mitigation education with the details of $0.08 \%$ for class VII, $0.19 \%$ for class VIII, and $0.16 \%$ for class IX. Meanwhile, as many as $0.48 \%$ of the Junior High School science Basic Competencies using the $\mathrm{K}-13$ has the potential to be used as an integration of the natural disaster mitigation education with the details of $0.72 \%$ for class VII, $0.25 \%$ for class VIII, and $0.5 \%$ for class IX. The percentage indicates that natural disasters have not become the objects of the study of natural science phenomena in daily life of the students. This also indicates that disaster mitigation activities are still low in the community, especially in the academic world of the students.

The data would have been more valid if the samples had been taken from several schools using the KTSP or K-13 or both curricula. The samples were taken by distributing short questionnaires to 40 Professional Education for Science Pre-service Teacher (PPG IPA) participants consisting of 20 participants in nonspecial PPG areas and 20 participants in special are commonly called as the Bachelor Degree Education Program for Outermost, Frontier, and Underdeveloped Areas (SM3T). The results of all curricula used in the schools where the PPG taught in both non-special and SM3T areas are presented in the percentage. As many as $0.05 \%$ of the schools used the KTSP, $0.325 \%$ used the K-13, and $0.625 \%$ used both curricula. In the non-special areas, as many as $0.4 \%$ of the schools employed the $\mathrm{K}-1$, while $0.6 \%$ of them used both curricula. On the other side, among the schools in the SM3T areas, as many as $0.1 \%$ used the KTSP, $0.25 \%$ used the K-13, and 0.65 used both.

\section{CONCLUSION}

The purpose of this study is to determine the percentage of the Competency Standards (SK) and the Basic Competencies (KD) in the SchoolBased Curriculum (KTSP), and the KD and the Core Competencies (KI) in the 2013 Curriculum (K-13) which can be integrated with disaster mitigation materials. In the KTSP, the $0.14 \%$ of the mitigation integration materials can be inserted in the KD with the details of $0.08 \%$ for class VII, $0.19 \%$ for class VIII, and $0.16 \%$ for class IX. In the $\mathrm{K}-13$, the natural disaster integration materials which can be inserted in the KD and KI are $0.48 \%$ with details of $0.72 \%$ for class VII, $0.25 \%$ for class VIII, and $0.5 \%$ for class IX. The data were collected to find out the percentage of Junior High Schools using the KTSP, the K-13 or using both of them. It was performed by distributing short questionnaires to 40 Professional Education for Pre-service Teacher (PPG) participants consisting of 20 participants from non-special PPG areas and 20 participants from the Bachelor Degree Education Program for Outermost, Frontier, and Underdeveloped Areas (SM3T). Broadly speaking, in Junior High Schools employing the PPG teachers, overall, as many as $0.05 \%$ of the schools 
used the KTSP, $0.325 \%$ used the K-13, and $0.625 \%$ used both curricula.

\section{REFERENCES}

Takahashi, K., Inomo H., Shiraki, W., Isouchi, C., Takahashi, M. (2017). Experience-Based Training in Earthquake Evacuation for School Teachers. IECMS Japan, 12, 782790

Hiwasaki, L., Luna, E., Syamsidik, Shaw, R. (2014). Process for integrating local and indigenous knowledge with science for hydro-meteorological disaster risk reduction and climate change adaptation in coastal and small island communities. ELSEVIER, 10, $15-26$

Richard Eiser, J., Bostrom, A., Burton, I., M. Johnston, D., McClure, J. (2012). Risk interpretation and action: A conceptual framework for responses to natural hazards. ELSEVIER, 1, 5-14

Spiekermann, R., Kienberger, S., Norton, J., Briones, F., Weichselgartner, J. (2015). The Disaster-Knowledge Matrix - Reframing and evaluating the knowledge challenges in disaster risk reduction. ELSEVIER, 13, 96107

M. Shreve, C., Kelman, I. (2014). Does mitigation save? Reviewing cost-benefit analyses of disaster risk reduction. ELSEVIER, 10, 213233

Gall, M., Hoan Nguyen, K., L. Cutter, S. (2015). Integrated research on disaster risk: Is it really integrated? ELSEVIER, 12, 255-264

Manandhar, S., Pratoomchai, W., Ono, K., Kazama, S., Komori, D. (2014). Local people's perceptions of climate change and related hazards in mountainous areas of northern Thailand. ELSEVIER, 11, 47-58

Contreras, D., Blaschke, T., Kienberger, S., Zeil, P. (2014). Myths and realities about the recovery of L'Aquila after the earthquake. ELSEVIER, 8, 125-142

Prajana Marwan Sejati. 2015. Ilmu Pengetahuan Alam Mitigasi Bencana Gunung Api kelas 4. Yogyakarta: Percetakan Amd

Pujianto. 2011. Analisis Proporsi Materi IPBA dalam Kurikulum Tingkat Satuan Pendidikan (KTSP) sebagai Dasar Pengembangan dan Pemahaman Materi Siaga Bencana di Sekolah. Yogyakarta: UNY

Ridwan Lasabuda. 2013. Pembangunan Wilayah Pesisir dan Lautan dalam Perspektif Negara
Kepulauan Republik Indonesia. Jurnal Ilmiah Platax, I-2 (ISBN: 2302-3589), 92101

Yakub Malik. Penentuan Tipologi Kawasan Rawan Gempabumi untuk Mitigasi Bencana di Kecamatan Pangalengan Kabupaten Bandung. Bandung: Jurusan Pendidikan Geografi FPIPS-UPI

Indyo Pratomo. 2006. Klasifikasi gunung api aktif Indonesia, studi kasus dari beberapa letusan gunung api dalam sejarah. Jurnal Geologi Indonesia, 1, 209-227

Raden Cecep Eka Permana, Isman Pratama Nasution, Jajang Gunawijaya. 2011. Kearifan Lokal Tentang Mitigasi Bencana pada Masyarakat Baduy. Makara Sosial Humaniora, 15, 67-76

A. Soehaimi. 2008. Seismotektonik dan Potensi Kegempaan Wilayah Jawa. Jurnal Geologi Indonesia, 3, 227-240

Danny Hilman Natawidjaja. 2007. Gempabumi dan Tsunami di Sumatra dan Upaya untuk Mengembangkan Lingkungan Hidup yang Aman dari Bencana Alam

Peraturan Menteri Pendidikan dan Kebudayaan (Permendikbud) nomor 61 tahun 2014 tentang KTSP

Peraturan Menteri Pendidikan dan Kebudayaan (Permendikbud) no 24 tahun 2016 tentang K-13

Sunyono. 2011. Mengkaji Model Pembelajaran Terpadu dalam Bingkai Kurikulum Terintegrasi. Fakultas Pascasarjana: UNNESA

Wahyudi Citrosiswoyo. 2005. Disaster Awareness in Primary Schools (DAPS) Tektonik Lempeng dan Gempabumi. Jakarta: Departemen Pendidikan Nasional Direktorat Pendidikan TK dan SD

Hery Harjono, dkk. 2007. Kesiapsiagaan Masyarakat: Kajian dan Pembelajaran untuk Mengantisipasi Gempabumi dan Tsunami. Jakarta: LIPI Pusat Penelitian Oseanografi

Goepfert, Dieter. 2006. Disaster Awareness in Primary Schools (DAPS) Gempabumi. Jakarta: Departemen Pendidikan Nasional Direktorat Pembinaan TK dan SD

J. Prager, Ellen, et al (diterjemahkan oleh Theodorus Dharma Wibisono, dkk). 2010. Bumi Murka: Sains dan Sifat Gempa Bumi, Gunung Berapi dan Tsunami. Bandung: Pakar Raya

Paulus Nugrahajati. 2012. Bencana Alam: Pencegahan dan Penanggulangannya. Jakarta: Wahyu Agria 